Meta

Journal des tradlucteurs

Translators' Journal

\title{
Translation as Literary Criticism
}

\section{B. Folkart Di Stefano}

Volume 27, numéro 3, septembre 1982

URI : https://id.erudit.org/iderudit/002571ar

DOI : https://doi.org/10.7202/002571ar

Aller au sommaire du numéro

Éditeur(s)

Les Presses de l'Université de Montréal

ISSN

0026-0452 (imprimé)

1492-1421 (numérique)

Découvrir la revue

Citer cet article

Folkart Di Stefano, B. (1982). Translation as Literary Criticism. Meta, 27(3),

241-256. https://doi.org/10.7202/002571ar

Ce document est protégé par la loi sur le droit d'auteur. L'utilisation des services d'Érudit (y compris la reproduction) est assujettie à sa politique d'utilisation que vous pouvez consulter en ligne.

https://apropos.erudit.org/fr/usagers/politique-dutilisation/
Cet article est diffusé et préservé par Érudit.

Érudit est un consortium interuniversitaire sans but lucratif composé de l’Université de Montréal, l'Université Laval et l'Université du Québec à Montréal. Il a pour mission la promotion et la valorisation de la recherche. https://www.erudit.org/fr/ 


\section{TRANSLATION AS LITERARY CRITICISM}

B. Follkart di Stefano

That literary translation should be informed by literary criticism is a truism; the purpose of this article is to reformulate this truism as the somewhat stronger statement that literary translation is intrinsically an act of literary criticism. Any translation, good, bad, as slipshod or haphazard as it may be, is inevitably a reading of a text: the type of translation to which $I$ shall be referring is a cerebral, coherent, highly deliberate reading of the text in relation to certain features considered relevant with respect to both its internal structures and its intertextual insertion. These views I shall illustrate by attempting to show how the literary translation process might deal with a number of specific problems arising in the translation of Sartre's novel, la Nausée, and in a short essay by Léonard Forest, entitled "Le pays de la Sagouine".

The first set of problems I shall deal with revolves about Sartre's use of tense to mirror the themes engendering and informing his work. It would be difficult to find another author who has used the system of tense and aspect as deliberately as Sartre to reflect his world view. Sartre's extreme sensitivity to the interplay of tense comes across eloquently in his essays on Faulkner and Camus, and his novel, la Nausée, appears in many respects to be the fruit of this sort of reflexion. It would not, I think, be stretching the point to state that, insofar as la Nausée is concerned, Sartre's view of tense precedes and indeed commands his use of tense. So much so that the boutade attributed to Alain Robbe-Grillet, who is reported to have said that "...le projet de Camus, lorsqu'il a eu l'idée de l'Étranger, était d'écrire un livre au passé composé ; après, pour le meubler, il a trouvé une histoire" ${ }^{1}$, would apply much more fairly, mutatis mutandis, to la Nausée, entire zones of which are, both formally and conceptually, as we shall see, structured about oppositions of tense.

Sartre's metaphorical use of the opposition between the passé composé and the passé simple is a very valid extrapolation of what Marc Wilmet has termed "la personnalité grammaticale" of the two tenses. It has long been observed by grammarians that, in terms of its effets de sens, the passé simple, by virtue of the relevant features which distinguish it from the passé composé and the imparfait ${ }^{2}$, lends itself very readily to the sequential ordering of events-

1. Quoted by Arne Klum, Verbe et adverbe, p. 170-171, note 3.

2. These relevant features being 1) the fact that the passé simple presents actions as unfolding in extenso (as opposed to the imparfait, which considers the event as only partially accomplished, its completion remaining in abeyance); 2) the fact that it very definitely implies an awareness of the limits within which the action is contained (again as opposed to the imparfait); and 3 ) 
hence its status of "le temps du récit par excellence" — and inevitably creates an effect of rupture with the present.

As opposed to the passé simple, which is one of the tenses in which the immanent aspect is conjugated and thus represents the event proper, the passé composé (sens plein) belongs to the transcendent aspect and focusses, not on the event itself, but on its aftermath : it has been pointed out that verbs in the transcendent aspect present their subject as being conditioned by past events rather than as having been the active agent of these events, this being the chief way in which Camus used the passé composé narratif to reflect the personality of his protagonist, Meursault, in l'Étranger ${ }^{3}$. Even when it is used as a passé composé narratif, i.e. as an allomorph of the passé simple, the passé composé retains to a considerable extent its blurred contours, establishing a subtle link with the present ${ }^{4}$ despite its collocations with non-contiguous adverbials (and this, of course, is why discours is characterized by the use of the passé composé, which, like the other shifters, refers constantly to the origin of coordinates constituted by the speaker, whereas histoire uses the passé simple $)^{5}$.

It is therefore an entirely natural consequence of their original aspectual properties that the passé simple should present past events as being divorced from the present and having sharp, clean contours, whereas the passé composé, which even in its narrative uses creates a sort of halo of "presentness" about the event in past time, blurs the contours of the event proper and presents it as extending in one way or another up to the moment of speech.

Now Sartre's trouvaille is to turn this basic opposition between the clean, sharply focussed, past passé simple and the out-of-focus, presently-relevant passé composé into an analogon of the world view he is presenting in la Nausée. The opposition between the two tenses thus ceases to be a purely grammatical one; it is now invested with a set of ideological significates ${ }^{6}$ : as used by Sartre (or rather by Roquentin, his persona), the passé composé narratif symbolizes the blurred contours of everyday existence before it has been apprehended by the mind, organized into thought and thus given meaning, the passé simple

the fact that it presents the event as being cut off from the present (as opposed to the passé composé (sens plein), which stresses contiguity with the present, and the imparfait, which is indifferent to the present).

3. Cf. Marc Wilmet (1976): Etudes de morpho-syntaxe verbale, Paris, Klincksieck, chap. 3, «Le passé composé narratif $»$, esp. p. 81.

4. Cf. A. Klum, op. cit., p. 168, note 6: «En employant le p. composé, on incorpore les événements, fussent-ils d'une époque tout à fait écoulée, avec l'actualité présente : il y a association psychologique, et les événements constituent pour cette actualité ce que Damourette et Pichon appellent un «acquêt».

The encroachment of the passé composé on the passé simple is symetrical with the tendency of the futur proche to gain ground at the expense of the futur: the marked tendency, in contemporary French, for these periphrastic forms based on a morphologically present component to displace the corresponding simple forms stems, possibly, from an underlying tendency to conceptualize all events in relation to the present.

5. See E. Benveniste's classic essays in Problèmes de linguistique générale, especially chap. XIX, "Les relations de temps dans le verbe français".

6. In fact, as used in la Nausée, the two tenses have three distinct sets of significates: 1) a grammatical significate (past + immanent), which they share as allomorphs; 2 ) the registral significates (histoireldiscours) which they convey as register markers; 3) the ideological significates peculiar to the ideolect of la Nausée. This last set of significates is the least stable and is neutralized in many parts of the novel (see note 7 ). 
offering a metaphorical equivalent of human experience re-organized into the mental structures which alone can render it meaningful ${ }^{7}$. This may be expressed as a homology :

$$
\frac{\text { passé composé }}{\text { passé simple }}=\frac{\text { flou du vécu brut }}{\text { le vécu réorganisé en signification }}
$$

This homology is of course highly relevant within the conceptual framework of la Nausée: the nausea to which Sartre is referring ("cette espèce de nausée dans les mains" 8 which Roquentin feels when a pebble picked up on the beach comes to life, so to speak, in his hands) is the gut reaction of his hero to the very idea that he, a human being, a potentially meaningful being, could exist at the level of insignificant matter. The proper business of living - at least for the Roquentin of the first half of the novel - is to organize into meaning the amorphous, unorganized events of everyday existence. The central idea of the book, then, its driving force is therefore the tension between the meaningful and meaningless, the formal and the amorphous. By using the opposition between passé composé and passé simple to reflect the terms of this dialetic, to concretize this polarization, Sartre is using form to reflect content, this being of course the highest aim of style.

One could find any number of examples to illustrate the use of tense as a structuring device. Perhaps the most blatant example is the embedding in the narration proper of passages presented as excerpts from historical works and set off from the matrix text, which uses the passé composé, by their use of the passé simple. In such embedded passages, the passé simple functions as a styleme, serving to differentiate the written word from its purportedly casual, semi-oral context and at the same time to connote - as in the case of the excerpts from Roquentin's historical study-the ideologeme "cuistrerie" or, more exactly, the futility of trying to superimpose on the past a single-valued and necessary interpretation. Even when the passages so embedded are not presented as examples of the written word, the rupture created by the use of the passé simple is exploited very effectively to ridicule the smug pseudo-certainties into which bourgeois ideology organizes existence along with the type of language in which such certainties are generally couched:

7. This perfusion of tense, while certainly deliberate, is far from systematic throughout the novel. It is used most frequently to establish a frontier between Roquentin's diary and the many texts quoted therein, thus functioning as a sort of opérateur citationnel. In the narration proper, however, it is used far less extensively: while there are indeed examples of its functioning in narrative passages (see p. below), there are others in which the opposition between passé composé and passé simple seems merely to reflect the aspectual properties of the two tenses or even, although much less frequently, to be characterized by random fluctuations (e.g. p. 110).

Grosso modo, the use of the two tenses as analoga of a world view seems to reflect Roquentin's initial assumption that the past can acquire transcendance, that it can be "saved" (p. 123) through conceptualization (and since it is, after all, Roquentin who is supposed to be writing this diary, the metaphorization of tense may be considered a feature of his style). And even though it is non-systematic, this perfusion of tense must be seen as stylistically relevant wherever it occurs and therefore as having very definite implications for the translation process.

8. Jean-Paul Sartre (1960): la Nausée, Paris, Gallimard, p. 23; see also p. 156 and 160. All subsequent references are to this edition. 
Je suis arrivée: voici la rue Tournebride[...]

Il y a seulement soixante ans nul n'aurait osé prévoir le miraculeux destin de la rue Tournebride, que les habitants de Bouville appellent aujourd'hui le petit Prado. J'ai vu un plan daté de 1847 où elle ne figurait même pas. Ce devait être alors un boyau noir et puant, avec une rigole qui charriait, entre les pavés, des têtes et des entrailles de poissons. Mais, à la fin de 1873, l'Assemblée nationale déclara d'utilité publique la construction d'une église sur la colline Montmartre. Peu de mois après, la femme du maire de Bouville eut une apparition: sainte Cécile, sa patronne, vint lui faire des remontrances. Était-il supportable que l'élite se crottât tous les dimanches pour aller à Saint-René ou à Saint-Claudien entendre la messe avec les boutiquiers? [...]

Ces visions furent agréées : le Conseil municipal tint une séance historique et l'évêque accepta de recueillir les souscriptions [...] (p. 60-61)

So too in the passage where Roquentin, describing the little old ladies casting respectful glances at the statue of Gustave Impétraz, remarks that :

Elles ne doivent pas savoir le nom de ce géant de bronze, mais elles voient bien, à sa redingote et à son haut-de-forme, que ce fut quelqu'un du beau monde. Il tient son chapeau de la main gauche et pose la main droite sur une pile d'in-folio [...] Elles n'ont pas besoin de le regarder longtemps pour comprendre qu'il pensait comme elles, tout juste comme elles, sur tous les sujets. Au service de leurs petites idées étroites et solides il a mis son autorité [...] : les saintes idées, les bonnes idées qu'elles tiennent de leurs pères, elles n'ont plus la responsabilité de les défendre; un homme de bronze s'en est fait le gardien. (p. 44)

Here again, the use of the passé simple, "fut" (in close proximity to the two passé composé sens plein "il a mis" and "il s'en est fait") signals the neat little pseudo-truths which the little old ladies derive from a correct reading of the monument, whose relevant features (redingote, haut-de-forme, plus, undoubtedly, the fact that it is made of bronze and offered up on a pedestal in a public square for the edification of passers-by) alert them to its ideological content: "bien pensant".

Now, the possibility of investing the two tenses with a supplementary set of meanings stems of course from the fact that the two exist as registral variants of one another in the first place, which in turn is due to the fragmentation of the evolving French verb system into histoire, characterized by the use of the passé simple wherever a preterite is required, and discours, in which the passé composé has usurped the functions of the passé simple. The English verb system, on the other hand, seems to be extremely stable in this respect, offering no such allomorphs to be exploited as the poles of an ideological opposition: all preterites, whether passé simple or passé composé narratif, map over into a single form in English, the simple past (as is generally the case with that other stylistic and structural variant of the passé simple, the imparfait pittoresque, which, in all but a handful of contexts, is rendered in English exactly as if it were a passé simple). It follows that there is a loss of stylistic information every time a stylistically marked passé composé narratif is translated into English, just as there is a loss of stylistic information every time one must render in English a passé simple used in a context where the stylistically unmarked term would be the passé composé : the English tense system offers no device 
for rendering either the casual effect of a stylistically marked passé composé narratif or the pedantic effect of a stylistically marked passé simple ${ }^{9}$.

To return to la Nausée, the loss of stylistic information entailed by the fact that both the passé simple and the passé composé narratif become simple pasts in English renders inoperative, in the mapping from French to English, the whole carefully structured, highly intellectualized model whereby the opposition between tenses parallels the opposition between amorphous reality and organized thought. The much more stable English tense system offers no registral variants with which the simple past could enter into an opposition to express this dialectic tension between the meaningful and the meaningless. And yet, I think, it is possible, in certain specific cases, to reproduce the functioning of this ingeneous model by having recourse to devices other than tense.

One of the most remarkable examples of the use of tense to mirror the dialectic underlying the whole book is the passage (p. 66-70) in which Roquentin stops off at the brasserie Vézelize to have lunch one Sunday. At one point, Sartre has Roquentin take out a copy of Balzac's Eugénie Grandet and read a few lines somewhat absent-mindedly, before being distracted by the conversation at the next table. This is of course a device for embedding a written text, specifically a literary work (and as such a prime manifestation of experience organized into meaning) ${ }^{10}$ in what is purportedly a slice of amorphous reality. It is carried off masterfully by Sartre, who creates a sort of contrapuntal arrangement in which the dialogue of Eugénie Grandet is interwoven with the vulgarly down-to-earth ruminatings of the couple at the next table.

The rupture between Eugénie Grandet and the slice of reality in which it is embedded is signaled by a number of markers : the typographical layout (the use of quotation marks and italics to set the passage off from the rest of the page); the contrast in tone (quoted passages are invariably coloured in one way or another by the context in which they are embedded, and the fragment of Eugénie Grandet comes across as being somewhat stilted in contrast to the vulgarity of the surroundings); and, of course, the dichotomy between passé composé and passé simple, which, like the typographical features of the text, functions as a sort of operateur citationnel (and it is probably no accident that the very sentence which establishes the frontier between matrix text and embedded text, between life and literature, contains a passé simple).

In this particular case, then, as elsewhere in the book, the opposition between the meaningful (of which the novel is obviously one of the highest

9. Nor does tense alone allow one to render in English the pretentious, "petit-bourgeois" quality of infra-literary texts which seem to operate on the basic assumption that literature without the passé simple is simply not literature and that, conversely, a liberal sprinkling of passé simple suffices to make literature out of texts otherwise singularly devoid of literary qualities ("nous nous frayâmes un passage au milieu des journalistes", etc., etc. in the French edition of Sophia Loren's mémoires).

10. Whether Roquentin finds this meaning existentially relevant is another story. While Eugénie Grandet emerges as being distinctly more meaningful than the background conversation of the bovine couple at the next table, its exact status in the value system of la Nausée is somewhat ambiguous. Like its structural variants (la Chartreuse de Parme, le Docteur au fouet), which also are picked up at random and read absent-mindedly, simply because they happen to be lying about, Eugénie comes across as being irrelevant, at cross purposes with everyday life, i.e., ultimately, with life. 
manifestations) and the meaningless is signaled by a redundant set of markers, most of which can be carried over into the English rendering. One can perhaps even find a substitute for the one set of markers (passé composélpassé simple) that cannot be transposed directly into English: in rendering this passage, the translator might make the tactical decision not to translate the fragment of Eugénie Grandet himself, so as to avoid its being rendered the same 1981, North-American usage as its context; he would instead hunt about for a rather outmoded, stilted-sounding translation of Balzac's novel (perhaps old-fashioned British usage as opposed to current North-American usage would be an adequate device for stressing the rupture, although one would of course be careful not to wind up with a caricature). His translation of this passage would reflect a very conscious, analytical process, bringing to bear on the fragment everything he knew about what might be termed la théorie $d u$ cadre (Baudelaire's idea that art is enhanced by being artificially set apart from reality ${ }^{11}$ - and Sartre's admiration for Baudelaire is well known, as is the anti-naturism which he shares with Baudelaire). The translation process would thus involve a conscious decision to "frame" these excepts so as to establish them as a literary space quite distinct from the supposedly non-literary space in which they are embedded.

Fortunately for the English translator, the opposition between the passé composé and the passé simple is not the only play on tense used to convey the fundamental meaning of the novel. It is, in fact, from the grammatical and ideological standpoints, only a special case of the opposition between past and present time-spheres, the passé composé (sens plein) being of course the present of the transcendent aspect, whereas the passé simple is the past of the immanent aspect. And this opposition between past and present is itself perfused with meaning, at least in that part of the novel in which Roquentin is still labouring under the "illusion" that events past have a necessary and single-valued transcendance in our conceptualization of them : in this world view, the present is the sphere of the immanent, of amorphous, as yet unorganized reality, du vécu brut en attente d'une signification, one might say, the past being the sphere in which unorganized reality accedes to transcendance, i.e. to meaning ${ }^{12}$.

11. Cf., in particular, the celebrated sonnet "Le Cadre" (Fleurs du Mal, XXXVIII.III, éd. Crépet et Blin) :

Comme un beau cadre ajoute à la peinture,

Bien qu'elle soit d'un pinceau très-vanté,

Je ne sais quoi d'étrange et d'enchanté,

En l'isolant de l'immense nature...

12. This world view is rejected later on, when Roquentin, like Anny, realizes that the conceptualization of the past is an inauthentic type of formalisation, i.e. an inauthentic attempt to put life in order, first of all because it postulates, erroneously, that events have a finality external to their narrator, so that one can arrive at an unequivocal and necessary reading of them and, secondly, because it, like Anny's stage appearances (p. 191) and her sporadic attempts at recounting to herself the past she shares with Roquentin (p. 191-192), remains external to the conceptualiser. As long as Roquentin still believes in "history", however, the concept of raconter (i.e. of ordering past experience) remains central, as does the opposition by virtue of which the present is negatively connoted with respect to the past (cf.: Je suis rejeté, délaissé dans le présent. Le passé, j'essaie en vain de le rejoindre: je ne peux m'échapper, p. 50 , as well as the feeling of being délaissé dans le présent (p. 123) experienced by Roquentin in the presence of the fallacious certainties proclaimed by the portraits of eminent Bouvillois those manifestations of l'homme repensé par l'homme (p. 117) — exposed in the Museum).

Within the framework of this "fallacy", since the past is the only sphere which lends 
This very subtle metaphorization of the distinction between past and present structures the entire passage in which Sartre describes Sunday in Bouville. The first part of the passage uses the présent narratif up through the scene in which Roquentin lunches at the brasserie Vézelize: it can be summed up by the phrase C'est dimanche. Once Roquentin has left the brasserie, at about three p.m., however, there is a shift in perspective, as reflected by the phrase C'était dimanche; the waning of the afternoon and the arrival of dusk are described exclusively with the past tenses, the imparfait, the passé composé narratif and, more and more frequently, until it predominates at the very end of the passage, the passé simple. The shift in tense reflects a sort of forward drift of narrative perspective from contemporaneous narrative to discours to histoire, corresponding to the enunciator's increasing distanciation with respect to the events described. Given the conceptual framework of the novel, the metaphorical value of this play on tense is evident: C'est dimanche/C'était dimanche : at twilight, as it begins to merge into the past, the day just lived enters the zone in which it can begin to acquire meaning. And in rendering this passage, the translator is well advised to render the présent narratif by a narrative present, however "un-English" this device may seem to certain linguists, in order to preserve the distinction between time-spheres, which, as we have seen, is so meaningful within the framework of the novel.

The narrative present should also be used to render the handful of episodes, scattered throughout the novel, in which it is the present, precisely, which is invested with meaning. Such episodes constitute a series of aventures, as Roquentin puts it, characterized by the fact that experience is instantaneously conceptualized, so that the event and its meaning are simultaneous and the contingent acquires significance. Tense-wise, such episodes are structured about the present, whether it be of the immanent aspect (the présent) or the transcendent aspect (the passé composé sens plein), with occasional recourse to the imparfait, the passé composé narratif or even to the passé simple, reduced henceforth to the status of mere allomorphs, the ideological opposition between passé simple and passé composé, between past and present, having been neutralized in such passages. From the standpoint of tense structuring, these aventures readily map over into English, the only loss being the inevitable registral one.

Ideally, then, the translator should perceive - the more explicitly the better - the ideological values underlying the use of tense in la Nausée; he must see the choice of tense as an artistically meaningful one, in most cases, and not just the result of random fluctuations due to the co-existence of the passé composé and the passé simple. In other words, he must perceive the text within a framework of critical analysis and translate accordingly.

And of course it must be borne in mind that tense is not the only device used by Sartre to flesh out his ideological views. The oppositions between

itself to recounting, i.e. in which the flow of time can be reversed (re-presented in relation to a finality), the past alone is meaningful, and one arrives at an extended homology (based on p. 57-8):

$\frac{+ \text { meaning }}{- \text { meaning }}=\frac{\text { aventure }}{\text { événement }}=\frac{\text { raconter }}{\text { vivre }}=\frac{\text { le temps à l'envers }}{\text { le temps en sens normal }}$ 
present and past, between passé composé and passé simple are only two avatars of the underlying opposition between the meaningful and the meaningless, an opposition which shapes the semantic structures and the vocabulary actualizing them from one end of the book to the other, the meaningless being expressed by dysphoric lexical items such as visqueux, vitreux, mou, moite, fade, terne, végétal, doux, sucré, sirop, liqueur, etc., whereas the meaningful surfaces in euphoric lexemes such as net, ferme, consistant, vif, tranché, dur, rutilant, métallique, minéral, etc. Obviously, lexical devices such as these can be carried over into English much more readily than certain oppositions of tense. Even apparently episodic elements such as the faces described by Roquentin are less descriptions than clusters of semiotically relevant features to be decoded ${ }^{13}$ in terms of the underlying opposition between the meaningful and the meaningless : Roquentin's own face in the mirror (une chair fade qui s'épanouit et palpite avec abandon. Les yeux surtout, de si près, sont horribles. C'est vitreux, mou, aveugle, bordé de rouge, on dirait des écailles de poisson, p. 31), as opposed to the petit visage ridé, propre et net of the historical (i.e. past, i.e. meaningful) figure Rollebon, who ressemblait, avec tout ce blanc et tout ce bleu - note the well-defined contrast - à un fromage de Roquefort (p. 31-32); as opposed also to the faces nettes comme des faïences of the rich and powerful Bouvillois of yesteryear immortalized in the Musée de Bouville: faces both past and conceptualized, endowed therefore with an exceptionally high density of meaning, truly l'homme repensé par l'homme (p. 117), summits of pre-digested meaning fully worthy of the ingenuous visitor's admiring gasp: Parrottin, de l'Académie des Sciences, par Renaudas, de l'Institut. C'est de l'Histoire ! (p. 118). The translator should be keenly aware of the semiotic and semantic structures underlying these passages and should do everything in his power to see to it that they are actualized as effectively in his translation as in the original.

He should also be extremely sensitive to the different shifts in perspective used by the author to reflect his attitudes toward the reality he is describing. One such shift in perspective is the deliberate distortion of reality achieved, for ideological purposes, by apprehending a conventional situation from the outside rather than in relation to its internal finality. The effect of such a distortion is to strip the situation thus described of its generally accepted meaning, to render it absurd by describing it in terms of features which are irrelevant or at least peripheral to the conventional meaning and which are selected so as to set up an isotopy radically different from the one that is usually accepted.

A prime example of this process is afforded by the following lines, describing Sunday in Bouville :

C'est dimanche : derrière les docks, le long de la mer, près de la gare aux marchandises, tout autour de la ville il y a des hangars vides et des machines immobiles dans le noir. Dans toutes les maisons, des hommes se rasent derrière leurs fenêtres: ils ont la tète renversée, ils fixent tantôt leur miroir et tantôt le ciel froid pour savoir s'il fera beau. Les bordels ouvrent à leurs premiers clients, des campagnards et des soldats. Dans les églises, à la clarté des cierges, un homme boit du vin devant des femmes à genoux. (p. 59)

13. Cf. p. 153: "Aveugles humanistes! Ce visage est si parlant, si net - mais jamais leur âme tendre et abstraite ne s'est laissé toucher par le sens d'un visage". 
Described in such oblique terms, Sunday mass is stripped of all symbolic value and divested of anything which might give it the special status of a sacred rite (status which is already seriously compromised by the juxtaposition with bordels). By dwelling on externals and refusing to penetrate their symbolic substratum, Sartre succeeds admirably in replacing the "sacred rites" isotopy (which would be actualized by the terms "prêtre", "calice", "fidèles") by what one might term the "drunken cad" isotopy: (l'homme, voire le mufle qui se saoule devant des femmes à genoux). This, I feel, should be stressed a little more forcefully ("a man is drinking wine as women kneel before him") than was done by the translator of Nausea ("in the churches, in the light of candles, a man is drinking wine in the sight of kneeling women.") ${ }^{14}$

Much the same device is used to transform the peaceful influx of the working class out for a Sunday stroll into a sinister paramilitary type of operation posing a threat to the security of the bourgeois entrenched in their beaux quartiers (the ideological implications of this fragment being of course that this is precisely what the bourgeoisie deserves):

Dans tous les faubourgs, entre les murs interminables des usines, de longues files noires se sont mises en marche, elles avancent lentement sur le centre de la ville. Pour les recevoir, les rues ont pris leur aspect des jours d'émeute : tous les magasins, sauf ceux de la rue Tournebride, ont baissé leurs tabliers de fer. (p. 59)

In translating ${ }^{15}$, I would stress the isotopy "threat" (hemmed in, march, advancing inexorably on, stand ready for them, when riots break out, barricaded behind their iron shutters) - much more so than does Lloyd Alexander ${ }^{16}$. Here, as in the allusion to Sunday mass, the shift in isotopy is highly relevant; the deliberate distortion of the usual point of vue conveys a very definite message in each case, and the translator must get this across.

This type of distortion can also be achieved through the use of tense, as in the passages where Sartre dismembers and denatures the little social rituals which embody bourgeois bad faith in his eyes :

Sur l'autre trottoir, un monsieur, qui tient sa femme par le bras, vient de lui glisser quelques mots à l'oreille et s'est mis à sourire. Aussitôt, elle dépouille soigneusement de toute expression sa face crémeuse et fait quelques pas en aveugle. Ces signes ne trompent pas : ils vont saluer. En effet, au bout d'un instant, le monsieur jette sa main en l'air. Quand ses doigts sont à proximité de son feutre, ils hésitent une seconde avant de se poser délicatement sur la coiffe. Pendant qu'il soulève doucement son chapeau, en baissant un peu la tête pour aider à l'extraction, sa femme fait un petit saut en inscrivant sur son visage un sourire jeune. Une ombre

14. Nausea, translated from the French by Lloyd Alexander, New York, New Directions, 1964, p. 41.

15. ...In the churches candles flicker and a man is drinking wine as women kneel before him. Everywhere on the outskirts of town long black columns, hemmed in between unending rows of factory walls, have begun to march, advancing inexorably on the center of town. The streets stand ready for them, looking the way they do when riots break out : all the storefronts, except those in rue Tournebride, are barricaded behind their iron shutters.

16. ...In the churches, in the light of candles, a man is drinking wine in the sight of kneeling women. In all the suburbs, between the interminable walls of factories, long black processions have started walking, they are slowly advancing towards the centre of the town. To receive them, the streets have taken on the look they have when disturbance is expected, all the stores, except the ones on the Rue Tournebride, have lowered their iron shutters (p. 41). 
les dépasse en s'inclinant; mais leurs deux sourires jumeaux ne s'effacent pas surle-champ: ils demeurent quelques instants sur leurs lèvres, par une espèce de rémanence. Quand le monsieur et la dame me croisent, ils ont repris leur impassibilité, mais il leur reste encore un air gai autour de la bouche. (p. 64-65)

Here the présent narratif and the passé composé are used very effectively to atomize the sequence of movements, to isolate the individual frames from the context into which they would normally blend to produce one continuous flowing motion, to cut them off from what precedes and what follows, thus rendering them grotesque, absurd, meaningless : des grimaces figées. This passage, with its distortion achieved through slow motion, is thus the dynamic equivalent of the out-of-focus, static type of distortion cultivated, with a sort of délectation morose, by Roquentin as he observes his face in the mirror (p. 30-31) or his hand (p. 127-128) at a distance or at an angle calculated to rob them of their everyday appearance and therefore of their meaning. The passé composé used to achieve this effect in the slow-motion passage are of course passé composé sens plein ("il s'est mis à sourire", "ils ont repris leur impassibilité"), and the translator can achieve exactly the same effect by using the present perfect.

In dealing with the different levels of expression in la Nausée, I referred rather superficially to the question of lexical choice as an expression of underlying semantic structures. I should now like to go a little further into this question a propos of Léonard Forest's "Le pays de la Sagouine", a short essay published as part of the preface to Antonine Maillet's la Sagouine ${ }^{17}$.

From the stylistic standpoint, perhaps the most striking thing about the essay is its simplicity, a sort of transparency which in no way precludes a distinctly poetic use of language, as evidenced by the plays on sound, particularly the alliterations on s (Il me semble qu'il y a un silence qui persiste jusqu'à ce jour dans ces villages baignés d'eau. Je ne sais si le souvenir tacite de Grand'pré et le poids d'une espèce d'immense deuil insurmontable y fait encore baisser les voix, etc.) and, at the macrostylistic level, by the way in which the very limpidity of the text echoes the metaphorical harmonics awakened by the multiple allusions to water. All in all, then, this little essay is extremely successful in recreating a literary equivalent of the muted, hushed reality it evokes.

It is also remarkable for the density of its lexical and semantic structures. As such, it lends itself admirably to a componential analysis type of approach.

From the standpoint of surface structure, the text is an interweaving of three different themes : I) "Le pays de la Sagouine n'est pas un pays d'exil", a theme which is developed in the first two paragraphs as a relatively detached review of historical data, using in a sporadic and fairly prosaic fashion much of the vocabulary which will be invested with poetic overtones in the rest of the text; II) the theme of water and silence (lines $25-48$ ), followed by a return and reworking of theme I (Ce n'est pas un pays d'exil, ni d'absence ni de froidure), modulating into theme III, the theme of time and silence and water (1.50-56).

The density of the text is of course a result of its tightly-knit lexical structures, which, in turn, owe their cohesiveness to the fact that they actualize

17. Nouvelle édition, Montréal, Leméac, 1974, p. 9-11. Part of the essay is reproduced below, p. 254-255. 
a very small number of underlying semantic markers to which the surface lexical structures must be reduced by the reader/critic/translator and which must be perceived by him as forming the conceptual nucleus from which the translation will be generated.

These surface structures are of course revealed by the extremely high frequency of certain lexical items : even the most casual reading of the text reveals that, in terms of sheer frequency, theme II is dominated by the words EAU and SILENCE, whereas theme III is dominated by references to le TEMPS. An inventory of the terms related to EAU, SILENCE and TEMPS reveals what may be called, to borrow Mauron's expression, the associative network of the text.

Semantic structuring of $2^{\text {nd }}$ and $3^{\text {rd }}$ themes

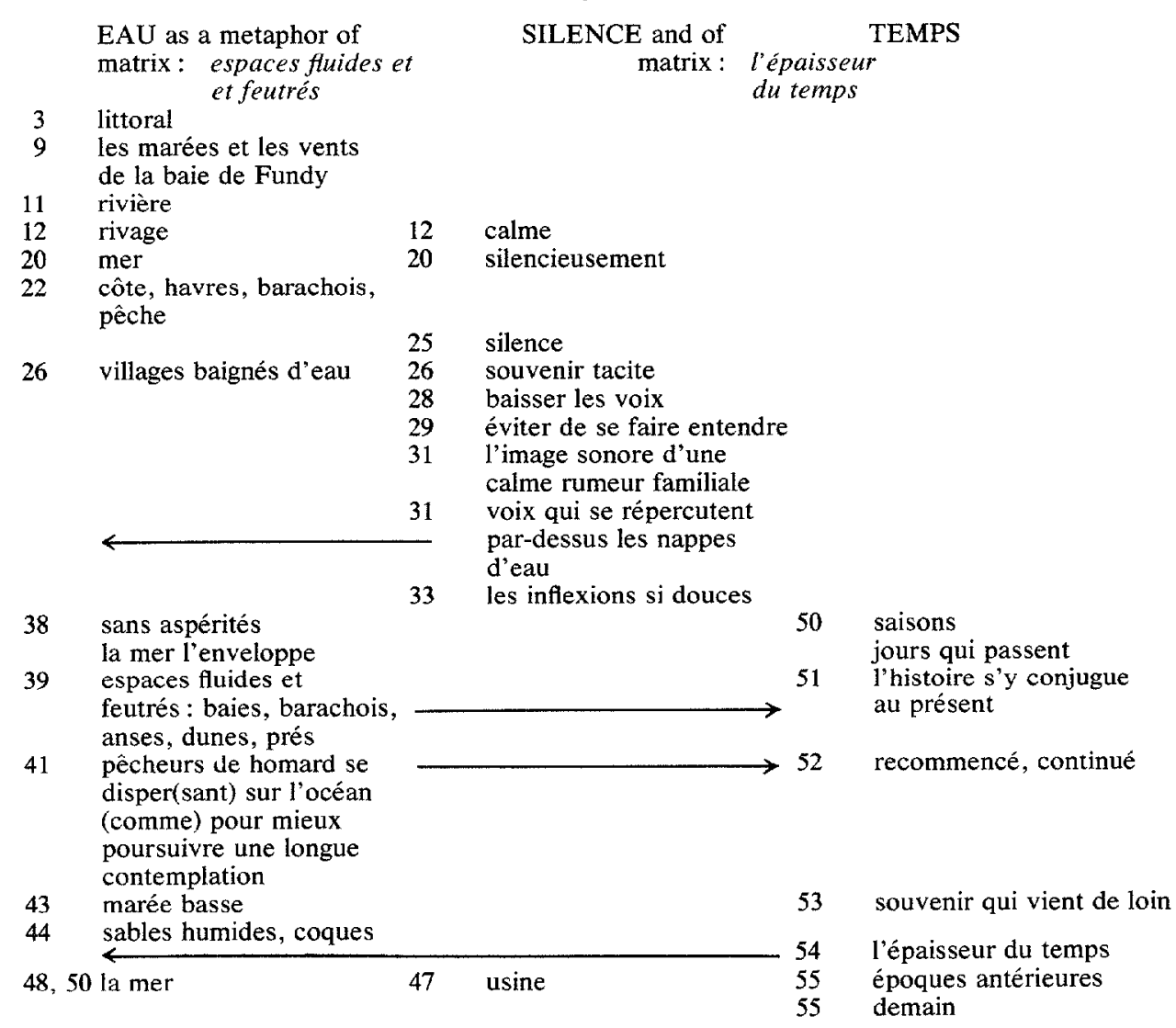

Now the underlying semantic structures of the text surface in two fundamental expressions which link in a non-prosaic way the notions of EAU and SILENCE, of EAU and TEMPS : these expressions I refer to as the matrices of the text because they engender its semantic and lexical structures.

The first of these matrices is the noun phrase espaces fluides et feutrés (1.39), which establishes EAU as a metaphorical equivalent of SILENCE by 
means of the linguistic "coupling", to borrow S. Levin's term, which their common grammatical function (both are modifiers of espaces) and, above all, their phonetic similarity (alliteration on $f$ ) sets up between the words fluides (EAU) and feutrés (SILENCE). This sort of coupling has been described by R. Jakobson ${ }^{18}$, who long ago pointed out that "En poésie, toute similarité apparente dans le son est évaluée en termes de similarité et/ou dissimilarité dans le sens", (hence the effectiveness of rhyme as a poetic device). Thus it is that the alliterative link between the words fluides and feutrés establishes a semantic equivalence between the two terms, so that EAU (fluides) becomes a metaphor of SILENCE (feutrés). The matrix espaces fluides et feutrés thus engenders, so to speak, the entire secondary theme, with its constant allusions to silence (silence, souvenir tacite, baisser les voix, éviter de se faire entendre, calme rumeur familiale, inflexions si douces) and to water (villages baignés d'eau, la mer l'enveloppe, baies, barachois, anses, dunes, l'océan, etc. etc.) Clearly, once silence is considered as a sort of enveloping fluid, the semantic marker common to "silence" and "eau" is "fluidity", which is actualized by many of the terms appearing in the inventories EAU and SILENCE and functions as what T.A. Van Dijk has termed a "sème thématique" 19 .

The thematic marker "fluidity" common to the notions of EAU and SILENCE generates yet another couple, EAU and TEMPS, as expressed by the second matrix, l'épaisseur du teimps (1. 54), which establishes EAU as a metaphor of TEMPS also. This second equivalence, which, independently of this specific text is a common enough one anyway (time flows, of time and the river), follows almost automatically from the first through a phenomenon which le Group $\mu$ has baptized l'ensemencement $d u$ texte ${ }^{20}$ : once a given metaphorical relationship has been uncovered at several points in the text, it tends to color, retrospectively and prospectively, the entire text (the classic example being that of François Villon, where the existence of a few unequivocally obscene metaphors induces the reader to see obscene allusions everywhere in the text ${ }^{21}$ ). Thus, a reader sensitive to the way in which the text is permeated by references to fluidity can only decode the phrase l'épaisseur $d u$ temps as the depths of time, not "layers" or "density" or "accumulation" or what have you, and certainly not prosaic renderings like "the measure of time", which would correspond rather to the French "la dimension historique" and would be completely beside the point. Thus it is that a single thematic marker structures the greater part of the text: EAU, SILENCE and TEMPS all have in common their enveloping fluidity.

So much for literary criticism. What really concerns us here is the interplay between literary analysis and the process of translation. I'd like to describe this interplay as it affects the translator's choices at a few specific points of the text.

First of all, there's the problem of translating the phrase espaces fluides et feutrés, which deserves particular attention since it plays a vital rôle in structuring

18. Essais de linguistique générale, p. 235, 240.

19. See, in particular, T.A. Van Dijk (1969): "Sémantique structurale et analyse thématique", Lingua 23, p. 28-54.

20. See, in particular, $\mathrm{Ph}$. Dubois (1975): "La métaphore filée et le fonctionnement du texte", Le Français moderne 43, p. 202-213.

21. Cf. Evelyn Birge Vitz (1974): The Crossroad of Intentions, The Hague, Mouton, chap. 1. 
the text. Here one immediately runs into a problem : the alliteration on $f$ is allimportant in establishing the metaphorical equivalence between eau and silence, and yet this alliterative link is lost in the process of translation, the only acceptable rendering of feutrés being "silent". Clearly then, the translator will have to compensate by paying particular attention to the way in which he renders espaces and fluides and combines the three terms into a noun phrase "visible" enough to stand out from the rest of the text. One might start out with the fairly prosaic rendering wet and silent places, but wet refers to the fluidity of water only, not of silence or of time, a superficial fluidity at that, one which might apply to the bays, inlets and coves mentioned in the text but not to the "fluance" of landforms such as the dunes and meadows referred to, which are fluid because their gently rolling contours mimic waves. My choice, then, would be to render fluides by fluid and espaces by spaces, so as to draw attention to the expression by creating a stylistically marked combination, fluid spaces (spaces are not ordinarily characterized as being fluid) and to replace the alliteration on $f$ by an alliteration on $s$ (silent fluid spaces), which would also be highly appropriate in the first lines of the translation. The final reading, silent, fluid spaces, places fluid and spaces in direct and unexpected juxtaposition and, hopefully, restores to fluid some of the "visibility" it has lost by being used in parallel with a word with which it is no longer in an alliterative relationship.

Clearly, if the notion of "fluidity" is as basic to the text as I believe, special care must be taken in rendering all the lexical items which actualize this isotopy. A particularly relevant example is the phrase ces villages baignés d'eau (1.26). One might start by observing that the author has chosen to say baignés d'eau and not "baignés par l'océan", "entourés d'eau/par la mer"; in other words, the collocation baignés +d'eau is in itself "abnormal" : surely, in a text as poetic as this one, this departure from the norm is a significant one. The possible English equivalents "washed by the sea", "coastal villages", etc., which would be objective descriptions of the reality outside the text and therefore perfectly appropriate in a geography book, are referential equivalents only and as such sacrifice both the notion of fluidity and the poetic overtones of the original. This is an excellent example of the fact that literary translation is perhaps the one area of translation in which the ad sententiam technique, to borrow St. Jerome's expression, should not be used, for in the literary text, form, the interplay of sound and meaning, of meaning with meaning and sound with sound from word to word (connotations, harmonics) is all important. The ad sententiam technique follows a triangular trajectory from source-language expression to referent to target-language expression, whereas the raison d'être of the literary text is not in the referent but in itself, i.e. in the words which interweave to form it.

My perception of the semantic structures underlying the text would lead me to stress, in baignés d'eau, the enveloping type of fluidity common to water, time and silence, a notion which gives rise to a whole set of secondary harmonics, poetic, Bachelardian and Freudian connotations which do not seem the least inappropriate to the text: the type of envelopment suggested by baignés d'eau is an intermingling, a symbiosis (and - why not? - the maternal embrace of 
Mother Ocean, the primordial sea from which all life has sprung, the sea we carry within ourselves, the sea in which we form as foetuses: Antonine Maillet herself has written many passages in which these themes surface). I would seek, then, in my translation, to choose a term which would suggest the living interface between water and human society and leave room for the whole immense field of connotations bound up with the life-giving sea: hence my rendering, villages enveloped by the sea.

In conclusion, then, while it's all well and good to translate as a sensitive reader reacting to the text intuitively and intuitively recapturing in his translation many of the features that are stylistically or conceptually relevant in the original, a strong case can be made, I feel, for bringing the full apparatus of literary criticism to bear on the text before and while rendering it. Literature is a highly redundant type of message, saying the same thing simultaneously at many different levels : denotation, connotation, form, rythms and sounds all converge to form a unified whole. It's the translator's business to recognize, through a close critical reading of the text, the conceptual and aesthetic unity underlying these diverse manifestations and to see to it that they permeate as many levels of his translation as possible. I would submit that, despite the danger of distortions arising from too rigid a critical approach, any translation proceeding from an intelligent overview of the text is preferable to the sort of rendering achieved by merely plodding on, sentence after sentence, without having first evolved a very explicit idea of what the author's aims are and how he is using words to achieve them. Literary translation should be a critical reading of the text, that is, an analysis and, inevitably, an interpretation, but also a jouissance, a revelling in the text.

\section{Le pays de la Sagouine}

1 Le pays de la Sagouine n'est pas un pays d'exil. Si l'ancienne famille acadienne n'avait pas été arrachée à sa féconde prospérité, elle allait s'étendre déjà le long de ce littoral sud-est du NouveauBrunswick. Durant les quelques décades qui séparent de la Dispersion

5 la prise de possession britannique de l'Acadie originelle (celle de la Nouvelle-Écosse), un assez grand nombre d'Acadiens avaient franchi la frontière imprécise qui s'ouvrait sur l'Acadie française. Ils avaient fondé Beaubassin, dans l'isthme de Chignectou et, plus à l'intérieur, ils avaient occupé la vaste vallée de Memramcook. Les marées et les

10 vents de la baie de Fundy les rejoignaient jusque-là, en montant la rivière, mais ils n'avaient qu'à marcher deux jours de plus pour explorer un nouveau rivage, sinueux et calme, qui donnait sur le détroit de Northumberland. Il s'étendait du Cape-Tourmentin et du Cap-Pelé jusqu'à Bouctouche et Richibouctou, en passant par le Barachois, Chédiaque et Cocagne. Ce pays était aussi l'Acadie. Il l'est resté.

Évidemment, la grande expulsion n'a pas épargné les établissements de l'Acadie française, mais c'est vers une terre connue que remontèrent les Acadiens dispersés en Nouvelle-Angleterre. Ici, au moins, dans le sud-est du Nouveau-Brunswick, avec ses terres basses

20 familières et la connivence de la mer, ils reprenaient silencieusement possession d'un pays à vocation acadienne. Dans la grande vallée, et 
ailleurs, ils se remirent à cultiver leurs prés. Le long de la côte, ils choisirent les havres et les barachois les plus propices et adoptèrent un nouveau métier: la pêche.

Il me semble qu'il y a un silence qui persiste jusqu'à ce jour dans ces villages baignés d'eau. Je ne sais si le souvenir tacite de Grand' Pré et le poids d'une espèce d'immense deuil insurmontable y fait encore baisser les voix. Ou s'agit-il d'une habitude prise lors du retour, quand il fallut, pour mieux se ré-installer, éviter de se

30 faire voir ou entendre? Pour ma part, je garde de ce pays l'image sonore d'une calme rumeur familiale, faite de voix qui se répercutent, après le souper, de maison en maison et de village en village, par dessus les nappes d'eau. Les inflexions si douces, si déférentes de la langue acadienne continuent partout le pacte de la discrétion. Ce

35 n'est pas qu'on ne soit pas bavard ou friand de médisances, parmi une population où l'on dirait que tout le monde est cousin, mais on préfère se parler entre soi et se méfier de l'oreille étrangère...

Voici donc un pays sans aspérités. La mer l'enveloppe de tous côtés et multiplie les espaces fluides et feutrés : baies, barachois,

40 anses, dunes, prés. On y entend pousser la passe-pierre* les nuits de clair de lune! Dès les premières lueurs du jour, les pêcheurs de homard se dispersent sur l'océan, comme s'ils ne s'éloignaient que pour mieux poursuivre une longue contemplation. À marée basse, les femmes et les enfants iront fouiller les sables humides pour cueillir

45 des coques. En remontant la pente douce, le foin sent bon et l'on est surpris d'apercevoir au bout du champ la nouvelle école polyvalente, immense comme une usine et les yeux résolument fermés sur la mer!

Ce n'est pas un pays d'exil, ni d'absence ni de froidure. La

50 mer tempère les saisons et les rêves. On y vit tout proche des jours qui passent. L'histoire s'y conjugue au présent. On ne sait si l'on a recommencé quelque chose ici ou si l'on a simplement continué. Il y a bien ce souvenir qui persiste et qui vient de loin, mais il n'est que l'épaisseur du temps. On n'a pas à rappeler les faits et détails

55 des époques antérieures, car la fille du voisin aura dix-sept ans demain et elle se nomme Évangéline.

Léonard Forest, "Le pays de la Sagouine», dans A. Maillet, La Sagouine, nouvelle édition, Montréal, Leméac, 1974, p. 9-11.

\section{Translation of Lines 25-56}

There seems to be a silence that's lasted up to this very day in these villages enveloped by the sea. It is because hushed memories of Grand Pré, a sort of immense and never-ending grief still soften voices to a whisper? Or is it a habit acquired with the return, when those stealing back from exile thought it best, in order to regain their footing in this land, to make themselves as inconspicuous as possible? My own personal impression of this land is one of quiet sounds, the gentle murmur of family voices echoing out across the waters after supper, from house to house, from village to village. And everywhere, those gentle, deferent inflactions of the Acadian dialect which are yet another way of being discreet! Not that people don't like a good chat or a lovely piece of gossip in a village where everyone seems to be related, but they prefer to keep their gossip to themselves and they're careful what they say in front of outsiders.

All in all, then, a land with no harsh contours, merging into the surrounding sea amid a multitude of silent, fluid spaces : bays and inlets, the little coves called barachois sheltered behind their sandbars, dunes and meadows. When the moon is out at night you

\footnotetext{
* Herbe saline et comestible.
} 
can hear the samphire growing! With the first light of dawn the lobstermen put out to sea, as if for a long meditation. At low tide, the women and children will go digging for clams in the wet sand. As you go back up the gentle slope there's the fragrance of hay in the air and you're surprised at the sight of the new comprehensive school looming up, like a huge factory, across the field, its back deliberately turned to the ocean!

No, this is no land of exile or estrangement or chilling cold. Seasons and dreams are made temperate by the sea. One lives here in harmony with the passing days and history is in the present. It's hard to say whether something has been started anew here or simply carried on. To be sure, there's that lingering memory from way back, but that's just the depth of time. No need here to recall old events and happenings long gone by : the neighbor's daughter will be seventeen tomorrow and her name is Evangeline. 